\title{
Regulatory Cells and Transplantation Tolerance
}

\author{
Stephen P. Cobbold and Herman Waldmann \\ Sir William Dunn School of Pathology, University of Oxford, South Parks Road, Oxford OX1 3RE, \\ United Kingdom \\ Correspondence: stephen.cobbold@path.ox.ac.uk
}

\begin{abstract}
Transplantation tolerance is a continuing therapeutic goal, and it is now clear that a subpopulation of T cells with regulatory activity (Treg) that express the transcription factor foxp3 are crucial to this aspiration. Although reprogramming of the immune system to donorspecific transplantation tolerance can be readily achieved in adult mouse models, it has yet to be successfully translated in human clinical practice. This requires that we understand the fundamental mechanisms by which donor antigen-specific Treg are induced and function to maintain tolerance, so that we can target therapies to enhance rather than impede these regulatory processes. Our current understanding is that Treg act via numerous molecular mechanisms, and critical underlying components such as mTOR inhibition, are only now emerging.
\end{abstract}

Evidence for immune regulation and suppresEsive cells has pervaded the field of transplantation ever since the classic experiments that showed the feasibility of inducing allogeneic chimerism and tolerance in the neonate (Billingham et al. 1953, 1954). Throughout the latter half of the twentieth century, while adoptively transferrable suppression of graft rejection remained a consistent finding (Streilein and Gruchalla 1981; Hall 1985), various lymphocyte subsets with supposedly suppressive properties came and went, as the technologies used to characterize them were found to be inadequate or flawed. Only in the last 10 years, with the discovery that foxp 3 is a genetic determinant in autoimmunity and "master transcription factor" for a subset of $\mathrm{CD}^{+}$regulatory T cells (Fontenot et al. 2003; Hori et al. 2003; Khattri et al.
2003), has the study and exploitation of regulatory cells become a defining pursuit for the transplant community.

It was only with the development of monoclonal antibodies (mAbs) that targeted functional molecules on the surface of $\mathrm{T}$ cells that transplantation tolerance could be achieved in the adult mouse (Cobbold et al. 1986; Qin et al. 1989). Initially these mAbs were used to deplete $\mathrm{T}$ cells, allowing bone marrow to be given to achieve donor chimerism and tolerance to skin grafts in a manner analogous to the neonatal model. Intriguingly, however, where antibodies were used to block T-cell function, antigen-specific $\mathrm{T}$ cells were not always deleted, but rather seemed to survive in a state of relative unresponsiveness known as anergy (Qin et al. 1989; Leong et al. 1992; Scully et al. 1994). These anergic T

Editors: Laurence A. Turka and Kathryn J. Wood

Additional Perspectives on Transplantation available at www.perspectivesinmedicine.org

Copyright (C) 2013 Cold Spring Harbor Laboratory Press; all rights reserved; doi: 10.1101/cshperspect.a015545

Cite this article as Cold Spring Harb Perspect Med 2013;3:a015545 
cells failed to proliferate to their specific antigen in vitro, but were hyperesponsive to IL-2, which we now know is a feature of Treg.

The concept of reprogramming the peripheral immune system toward a state of transplantation tolerance was firmly established (Cobbold et al. 1992) with the discovery that a combination of functionally blocking mAbs against the T-cell coreceptors CD4 and CD8 could induce tolerance directly to allogeneic skin grafts (Qin et al. 1990). Tolerance was induced in the adult mouse without the need for T-cell depletion or stable chimerism and was found to be independent of the thymus. The tolerant state was also dominant-able to resist the infusion of a large number of naïve T cells, which was a strong pointer to the presence of immune regulation rather than any deletion of donor reactive $\mathrm{T}$ cells.

\section{LINKED SUPPRESSION AND INFECTIOUS TOLERANCE}

With the demonstration that the tolerance induced to allogeneic skin grafts in the periphery must involve some form of immune regulation, it became clear that we had to revisit the concept of suppression, despite considerable resistance from the immunological community at that time. The ability to adoptively transfer tolerance with $\mathrm{T}$ cells to secondary recipients had remained a consistent but mostly ignored theme even through the antisuppression era of the 1980s. But the availability of better reagents clearly associated suppression with the CD4 ${ }^{+}$ subpopulation of T cells (Qin et al. 1993) and not the $\mathrm{CD}^{+}$"cytotoxic/suppressor" cells of the past. These CD4 ${ }^{+}$"regulatory" T cells could not only transfer tolerance to secondary recipients, but they could also confer a state of tolerance onto new cohorts of naïve T cells - a process that merited the term "infectious tolerance" originally coined many years earlier (Gershon and Kondo 1971) to simply describe the phenomenon of suppression. In a similar fashion, tolerance could "spread" from one set of allogeneic antigens ( from strain A) on a tolerated graft to the second set of antigens ( from strain B) on a graft from a (strain A $\times$ strain B) F1 cross (Da- vies et al. 1996). This process was termed "linked suppression" to indicate that the two sets of antigens needed to be expressed, or linked, on the same APC.

\section{REGULATORY T CELLS AND AUTOIMMUNITY}

Around the same time that suppression was being revisited in transplantation tolerance, others working in certain rodent models of autoimmune disease were being faced with a similar challenge. In particular, it was found that $\mathrm{CD} 4^{+}$ T cells could be separated into two subsets on the basis of their expression of different isoforms of CD45-transfer of one of these subsets into immunodeficient secondary recipients caused a severe lymphoproliferative wasting disease, whereas addition of the other subset could suppress it (Powrie et al. 1994). This was interpreted as the former subset containing autoreactive $\mathrm{T}$ cells that required the presence of Treg in the latter subset to maintain immune homeostasis. A different model of autoimmunity had been pursued, particularly by Sakaguchi's group, where mice were thymectomized on day 3 after birth (Asano et al. 1996). The inflammatory gastritis that developed in this model could be prevented by the infusion of mature $\mathrm{CD} 4^{+} \mathrm{T}$ cells, and, once again, these could be separated into two subsets-in this case those that expressed CD25 were the regulatory subpopulation. Although there were strong similarities between the $\mathrm{CD}^{+}$regulatory subsets in the different autoimmune and transplantation models, there were also some apparent discrepancies (Alyanakian et al. 2003), and it was not until the discovery of foxp 3 as the causative gene of autoimmune disease in the scurfy mouse and the human IPEX syndrome that the field of regulatory $\mathrm{T}$ cells began to focus on a unique and unifying T-cell subset (Fontenot et al. 2003; Hori et al. 2003; Khattri et al. 2003).

\section{REGULATORY T CELLS AND Foxp3}

Foxp3 was identified as a transcription factor of the forkhead box family that, in both mice and humans, is required for the generation of the 
Regulatory T Cells

thymic $\mathrm{CD} 4{ }^{+} \mathrm{CD} 25^{+}$regulatory T-cell subset often termed "natural” Treg (nTreg). Transduction of the foxp3 gene was shown to convert naïve $\mathrm{T}$ cells into regulatory T cells (Fontenot et al. 2003; Hori et al. 2003) in a manner that recapitulated the suppressive functions previously ascribed to $\mathrm{CD} 4{ }^{+} \mathrm{CD} 25^{+}$cells in a range of autoimmune and transplantation models. Naïve T cells could be induced to express foxp3 and acquire at least some of the functions of regulatory $\mathrm{T}$ cells by activating them in the presence of TGF- $\beta$ in vitro (Chen et al. 2003). TGF- $\beta$-dependent conversion of naïve, peripheral $\mathrm{CD} 4^{+} \mathrm{T}$ cells into iTreg was also observed in vivo, particularly in TCR transgenic mice on a $\mathrm{RAG}^{-/}$- background (Cobbold et al. 2004; Kretschmer et al. 2005). Treatment of female mice expressing a TCR specific for the male transplantation antigen DBY, as presented by MHC-II, with a brief course of nondepleting anti-CD4 antibody, could induce lifelong tolerance to male skin grafts (Cobbold et al. 2004). This tolerance was associated with a peripheral induction of foxp3 expression with the Treg concentrated within the tolerated skin graft (Graca et al. 2002; Cobbold et al. 2006). Positive selection in the thymus for the male-specific TCR in $\mathrm{RAG}^{-/-}$background mice generated only naïve T cells, and foxp 3 expression could not be detected in the thymus, even by sensitive RT-PCR, indicating that tolerance in this model depended entirely on peripheral iTreg induction. Recently, the use of a mouse that expresses hCD2 on the cell surface as a reporter gene for foxp 3 expression has allowed proof that these foxp $3^{+}$Treg maintain transplantation tolerance (Kendal et al. 2011; Regateiro et al. 2012): administering a depleting $\mathrm{hCD} 2 \mathrm{mAb}$ caused rejection of the graft, either in the original recipients or in secondary $\mathrm{RAG}^{-/-}$ recipients of the tolerated graft, proving that foxp $3^{+}$Treg were actively regulating effector cells within the graft itself. Similar experiments in these hCD2 reporter mice also showed that the foxp $3^{+}$Treg were necessary for linked suppression and infectious tolerance in mice that had a normal polyclonal TCR repertoire, and when crossed onto DBY-specific TCR transgenic mice on a $\mathrm{RAG}^{-/-}$background gave confirmation that tolerance to male skin grafts depended on the peripheral induction of foxp $3^{+}$iTreg.

\section{POSITIVE SELECTION OF Treg, THEIR SPECIFICITY, EPIGENETICS, AND STABILITY}

Although the importance of nTreg in controlling autoimmunity and immune homeostasis is now generally accepted, the role of foxp $3^{+}$iTreg has remained more controversial. Despite the publication of a number of candidate markers distinguishing nTreg and iTreg, such as helios (Thornton et al. 2010) and neuropilin-1 (Yadav et al. 2012), these have not proven reliable, and may instead relate to different activation states of either cell type. The key feature that distinguishes nTreg from iTreg is the specificity of their TCRs (Lee et al. 2012). nTreg are positively selected with a moderate to high affinity for self-antigens, including peripheral, tissue-specific antigen peptides driven by AIRE on thymic epithelium (Aschenbrenner et al. 2007). This means that nTreg are always likely to meet a constant source of their specific "self"antigen in the periphery, which may be an important factor in their constitutive expression of molecules considered as markers of activation in non-Treg cells such as CD25, GITR, and CTLA4, and may also be a factor in their longevity and stability. In contrast, iTreg are derived from naïve $\mathrm{T}$ cells originally selected in the thymus with low affinities for self-antigen peptides, but likely to have higher affinities for the "foreign" antigen eliciting them in the periphery. Once the foreign antigen is eliminated, for example, if an allograft is rejected, the iTreg may lack sufficient TCR stimulus for continued maintenance or stability.

One important factor in the stability of Treg is the epigenetic status of the foxp 3 gene (Floess et al. 2007; Lal et al. 2009; Zheng et al. 2010), specifically the extent to which the intronic enhancer element known as the "Treg cell-specific demethylation region" (TSDR) is demethylated (Floess et al. 2007) to allow the access of a number of important positive transcription factors such as STAT5 and NF- $\kappa$ B as well as foxp3 itself (Fig. 1). This TSDR starts to be demethylated early in the differentiation of nTreg in the thymus, continues until nTreg in the periphery are fully demethylated, and is associated with stable foxp3 expression. Surprisingly, the 
S.P. Cobbold and H. Waldmann

\begin{tabular}{|c|c|c|c|c|c|}
\hline $\begin{array}{l}\text { Positive } \\
\text { transcription } \\
\text { factors }\end{array}$ & $\begin{array}{l}\text { Sp1 } \\
\text { TIEG1 }\end{array}$ & $\begin{array}{c}\text { TIEG1 } \\
\text { NFAT } \\
\text { AP-1 } \\
\text { RAR-RXR } \\
\text { Runx1/3 } \\
\text { Foxo1/2 } \\
\text { CREB } \\
\text { STAT5 }\end{array}$ & $\begin{array}{c}\text { NFAT } \\
\text { AP-1 } \\
\text { Smad3 } \\
\text { RAR-RXR }\end{array}$ & $\begin{array}{c}\text { CREB-ATF } \\
\text { STAT5 } \\
\text { Foxo1/2 } \\
\text { Runx } \\
\text { Cbfb } \\
\text { Foxp3 }\end{array}$ & c-Rel \\
\hline Exons & & \multicolumn{2}{|c|}{$-2 a-2 b$} & -11 & $2 \rightarrow 11$ \\
\hline Genome & $-\begin{array}{l}\text { Upstream } \\
\text { enhancer }\end{array}-1 /$ & $\begin{array}{l}\text { Proximal } \\
\text { promoter }\end{array}$ & \begin{tabular}{|c|} 
Enhancer \\
CNS1 \\
\end{tabular} & \begin{tabular}{|c|} 
Enhancer \\
TSDR \\
\end{tabular} & \begin{tabular}{|c|} 
Enhancer \\
CNS3
\end{tabular}$\rightarrow$ Foxp3 \\
\hline $\begin{array}{l}\text { Negative } \\
\text { transcription } \\
\text { factors }\end{array}$ & $\begin{array}{c}\text { STAT3 } \\
\text { MBD2 } \\
\text { MECP2 } \\
\text { DNMT1/3 }\end{array}$ & $\begin{array}{l}\text { GATA3 } \\
\text { Id3 } \\
\text { IRF1 }\end{array}$ & & STAT3 & \\
\hline $\begin{array}{l}\text { Primary } \\
\text { function }\end{array}$ & $\begin{array}{l}\text { Required } \\
\text { for stable } \\
\text { foxp3 } \\
\text { expression }\end{array}$ & $\begin{array}{l}\text { Required for } \\
\text { foxp3 } \\
\text { transcription }\end{array}$ & $\begin{array}{l}\text { Required } \\
\text { only for } \\
\text { iTreg } \\
\text { induction }\end{array}$ & $\begin{array}{l}\text { Demethyl- } \\
\text { ation } \\
\text { correlates } \\
\text { with Treg } \\
\text { stability }\end{array}$ & $\begin{array}{l}\text { "Pioneer" } \\
\text { element }\end{array}$ \\
\hline
\end{tabular}

Figure 1. Regulation of the foxp3 locus. The genomic organization of the foxp3 locus is depicted (not to scale) with the position of the most important regulatory elements shown, together with the positive and negative regulatory transcription factors that have been shown to bind to them and the primary function of each element.

demethylation process in nTreg has recently been shown to be independent of any actual foxp3 expression (Ohkura et al. 2012). In contrast, iTreg recently generated in vitro by TCR activation in the presence of TGF- $\beta$ have very little demethylation of the TSDR, and also rapidly lose stable foxp3 expression, particularly if TGF- $\beta$ is withheld from the culture. The epigenetic status and stability of iTreg induced in vivo as a result of tolerance induction remains unclear, although historical transplantation experiments suggested that regulatory $\mathrm{T}$-cell activity was maintained as long as the source of antigen (i.e., the allograft) was present (Scully et al. 1994).

It has been claimed that the addition of all transrentinoic acid (ATRA) or rapamycin during Treg expansion improves their stability in vitro (Zhou et al. 2010; Takahashi et al. 2012; Yurchenko et al. 2012), whereas others have attempted to provide IL-2/anti-IL-2 complexes with a long half-life in vivo to promote Treg activity (Daniel et al. 2010; Letourneau et al. 2010). Although we tend to think of T-cell subsets as fixed lineages proceeding to terminal differentiation, there are a number of examples showing "plasticity" allowing Treg cells to "transdifferentiate" into effector cells, although this remains controversial (Zhou et al. 2009; Rubtsov et al. 2010). One possibility is that plasticity and lineage diversification are generated by asymmetry during cell division, as has been observed during stem cell (Neumuller and Knoblich 2009) and $\mathrm{CD}^{+}{ }^{+}$-cell differentiation (Chang et al. 2007), whereas symmetric divisions expand and mature in cell populations without further diversification. The stability of in vitro induced or expanded Treg is particularly important for their potential use in proposed cellbased therapies, where Treg are given to transplant recipients to suppress alloreactivity and enforce tolerance to the graft. Identification of the mechanisms that stabilize Treg is a clear target for new strategies to enhance tolerogenic therapies.

\section{THERAPEUTIC APPLICATION OF Treg CELLS: WHICH Treg AND WHICH ANTIGENS?}

One of the first therapeutic applications considered for Treg was to limit graft versus host disease (GVHD) in allogeneic bone marrow and 
stem cell transplantation. Although GVHD can be eliminated by depleting any contaminating donor T cells from the marrow/stem cell inoculum, this increases the risk the graft may be rejected, and also removes any potential for a curative graft versus leukemia effect (Hale and Waldmann 1996). It has been repeatedly shown that the administration of an excess of purified or in vitro expanded nTreg from the donor inoculum can reduce GVHD and enhance tolerance in mouse models of bone marrow transplantation, without losing the GVL effect (Edinger et al. 2003; Sato et al. 2003; Trenado et al. 2003). An important safety issue for clinical transplantation is the purity and stability of the nTreg cells infused-they should not contain any regulation-resistant memory $\mathrm{T}$ cells, nor should they be able to revert to effector cells, either of which could potentially exacerbate GVHD rather than suppress it. As more markers are combined (e.g., $\mathrm{CD} 4^{+}, \mathrm{CD} 25^{\text {high }}, \mathrm{CD}^{+} 5 \mathrm{RA}^{+}$, CD $127^{\text {low }}$ ) (Liu et al. 2006) and the stringency of sorting is increased, then so will the yield of Treg decrease. This means that in vitro expansion (Earle et al. 2005) is likely to be needed for routine application, and the long-term stability of such cells remains questionable (McClymont et al. 2011).

A large excess of nTreg have been shown in mouse models to be able to induce tolerance to allogeneic skin grafts given to lymphopenic recipients, although they seemed to do so without any particular specificity for the donor antigens (Graca et al. 2004). This is in contrast to the Treg that have been induced in mice made tolerant to allogeneic skin grafts, by treatment with nondepleting mAbs, where regulation requires donor antigen (although this can then lead to linked suppression of additional antigens, as discussed earlier). This raises a number of questions as to whether therapeutic Treg cells should be derived from recipient nTreg or iTreg, should they be expanded or induced on antigen, and in the context of transplantation, whether antigen be presented in the context of donor (direct presentation) or recipient (indirect presentation) MHC (Jiang et al. 2004; Sanchez-Fueyo et al. 2007)? It would seem that Treg with specificity for both directly and indirectly presented donor antigens are the most effective at inducing tolerance to allografts (Tsang et al. 2009), and are considerably more potent than unselected nTreg (Chen et al. 2009; Veerapathran et al. 2011).

It remains a challenge as to how sufficiently large numbers of antigen-specific Treg, stably expressing foxp3, and uncontaminated by effector $\mathrm{T}$ cells can be generated for clinical therapy. Human T cells appear to have a more promiscuous expression of foxp3 than mouse Treg (Wang et al. 2007), such that demonstrable expression of foxp 3 alone may not be sufficient to ensure that the population will guarantee suppressive function in vivo. In addition, the usual in vitro readout for Treg function is the suppression of naïve T-cell proliferation, but as we do not yet know the molecular mechanisms of immune regulation, this assay may not faithfully reflect the in vivo efficacy. It is beyond the scope of this particular review to detail how attempts to develop clinical Treg therapy are progressing, as this topic is considered in more detail elsewhere in this collection.

\section{MOLECULAR MECHANISMS OF Treg FUNCTION}

One of the first identified properties of regulatory $\mathrm{T}$ cells was that they failed to proliferate in response to antigen or TCR stimulation in vitro-so called anergy (Qin et al. 1989; Schwartz 1990; Chen et al. 2004; Fu et al. 2004; Park et al. 2004). This is primarily associated with an inability to produce IL-2 for the autocrine stimulation of proliferation, although anergic cells may also overexpress the high-affinity IL-2 receptor (CD25) and be hyper-responsive to exogenous sources of IL-2 (Beverly et al. 1992; Setoguchi et al. 2005). This has led some to suggest that Treg function, at least in the in vitro suppression of proliferation assay, by preferentially consuming IL-2 (Shevach 2009). However, IL-2 is generally required for the survival of Treg, and mice deficient in either IL-2 or its receptor experience autoimmunity rather than immunosuppression (Horak et al. 1995; Kramer et al. 1995; Caudy et al. 2007). 
Another mechanism proposed for Treg function is the expression of granzymes that kill APCs (Shevach et al. 2006), thereby suppressing antigen presentation. The phenomenon of linked suppression strongly suggests that Treg act via modulating the APC is some way (Davies et al. 1996); but if all APCs were killed, then one has to question how antigen is presented to allow the induction of Treg. Specific killing of donor APC, however, could be a means to eliminate directly presented donor antigen to allow only indirect presentation by recipient APCs, which in the presence of TGF- $\beta$ could still induce Treg for tolerance.

TGF- $\beta 1$-deficient mice and mice expressing a transgenic dominant negative TGF-BRII on their T cells are both prone to develop autoimmunity (Shull et al. 1992; Shah et al. 2002). Under some conditions, Treg are themselves able to secrete TGF- $\beta$, or may have TGF- $\beta-$ LAP complexes expressed on their surface (Nakamura et al. 2001), tethered via a molecule associated with anergic cells called GARP (Tran et al. 2009). TGF- $\beta$ is known to be broadly antiinflammatory, and can also induce foxp3 expression and peripheral conversion of naïve $\mathrm{T}$ cells to iTreg, and has therefore been implicated as a mechanism of the cell contact-mediated suppression observed in vitro and infectious tolerance (Nakamura et al. 2004). Although we know TGF- $\beta$ signaling to $\mathrm{T}$ cells in vivo is required for the induction of tolerance and iTreg, there are many sources of TGF- $\beta$ other than Treg in vivo, and any TGF- $\beta$ generated requires activation by appropriate proteases or $\alpha 5$ integrins (Paidassi et al. 2010, 2011) not normally expressed on Treg. In addition, exposure of naïve T cells to TGF- $\beta$, while inducing some of the markers such as CD103 associated with Treg, only induces foxp3 in a proportion of exposed cells (Regateiro et al. 2012). If TGF$\beta$ exposed $\mathrm{T}$ cells are sorted using a reporter gene (e.g., hCD2, as above) then only the cells expressing foxp3 can transfer transplantation tolerance while the foxp 3 negative (but TGF- $\beta$ exposed $\mathrm{T}$ cells still cause graft rejection) ( $\mathrm{Re}-$ gateiro et al. 2012). All this suggests that TGF- $\beta$ secretion, at best, only explains part of the functional capabilities of Treg.
Two other cytokines that can be secreted by Treg are IL-10 and IL-35 (Collison et al. 2007). Both of these cytokines are considered to have anti-inflammatory functions and have been implicated in the mechanism by which Treg suppress in inflammatory bowel disease (Uhlig et al. 2006), experimental allergic encephalomyelitis (Sundstedt et al. 2003; Yu et al. 2005; Fitzgerald et al. 2007), collagen-induced arthritis (Mauri et al. 2003), and allergic airway inflammation (Whitehead et al. 2012). Like TGF- $\beta$, there are many sources of IL-10 other than Treg cells, and the importance of Treg-derived IL-10 in transplantation tolerance remains unclear. The more recently identified cytokine IL-35 is currently thought to be more specific to Treg, although there is very little data concerning other possible sources, partly because it consists of a specific combination of EBI-3 and p35 chains, both of which can pair with other members of the IL-12 family of heterodimeric cytokines. Whereas IL-10 is thought to limit the induction of inflammation, IL-35 seems to act much later to dampen down ongoing inflammatory processes (Whitehead et al. 2012). There is, as yet, very little information on any possible role of IL-35 in transplantation tolerance.

CTLA4-deficient mice also develop an autoimmune proliferative disease similar to foxp3deficient mice (Tivol et al. 1995). CTLA4 is transiently expressed on activated $\mathrm{T}$ cells, is constitutive on some foxp $3^{+}$Treg cells, and is thought to compete with the costimulatory binding of CD28 to B7 ligands on APCs. The high affinity of CTLA4 has even been observed to deplete B7 ligands from APCs by capturing and internalizing them on the T cells by a process termed "trogocytosis," thereby forcing the APCs into a less inflammatory and more tolerogenic mode of antigen presentation (Qureshi et al. 2011; Zhang et al. 2011). It is not yet clear how important this process is for Treg function in the context of transplantation, but mice with a conditionally inducible CTLA4 knockout allele in their foxp $3^{+} \mathrm{T}$ cells have shown that CTLA4 expression on Treg is continuously required to avoid the development of autoimmune disease (Sojka et al. 2009). 


\section{TOLEROGENIC MICROENVIRONMENTS AND THE ROLE OF LOCAL, INDUCED IMMUNE PRIVILEGE}

Although defects in Treg tend to cause a generalized lymphoproliferative disease, most autoimmune diseases are restricted to certain organs or tissues, suggesting a more localized loss of regulation. In TCR transgenic models of transplantation tolerance, the Treg seem to concentrate to the transplanted tissue and can be shown to act locally (Cobbold et al. 2006; Kendal et al. 2011). Evidence is now accumulating that peripheral tolerance is in part dependent on the induction of a form of immune privilege within the microenvironment of, and dependent on an active participation by, the tolerated tissue. Within the tissue, and potentially modified by the local microenvironment, are a number of different cell types that can present antigen on MHC-II antigens to Treg; some are migratory such as dendritic cells, macrophages, and B cells, but others are mostly resident, including endothelial cells and mast cells (Lu et al. 2006). Locally active TGF- $\beta$, whether derived from Treg or the tissue, may represent an important component of a tolerogenic microenvironment that can, for example, induce the expression of CD39 and CD73 on T cells, macrophages, and dendritic cells (Regateiro et al. 2011, 2013). CD39 and CD73 are two ectoenzymes expressed on the cell surface that are able to convert inflammatory extracellular ATP (released during cell damage) into AMP and then adenosine, which has anti-inflammatory properties by binding to adenosine receptors on $\mathrm{T}$ cells and dendritic cells and inducing the intracellular second messenger cAMP. Raised levels of cAMP have been associated with the anergy of Treg (Cone et al. 1996; Powell et al. 1999), and it has been suggested that infectious tolerance may be explained by cAMP, in essence, being passed from Treg to induce an anergic state in nearby naïve T cells, either via the CD39/CD73-mediated adenosine pathway, or perhaps directly via the formation of tight junctions between adjacent T-cell membranes (Bopp et al. 2007).

Treg can themselves also contribute to a state of immune privilege by inducing the local expression of enzymes that catabolize essential amino acids (EAAs) (Cobbold et al. 2009). IDO (indoleamine dioxygenase), that catabolizes tryptophan, was the first such enzyme to be shown as important in maintaining a form of transplantation tolerance in mice, as the specific inhibitor 1-MTwas able to cause the rejection of fetuses expressing allogeneic, but not syngeneic, paternal antigens (Munn et al. 1998). It has recently been suggested that maintenance of tolerance to the allogeneic fetus may be the main physiological role for peripherally induced iTreg cells, particularly as the TGF- $\beta$ responsive elements (Zheng et al. 2010) of the foxp3 enhancer appeared in evolutionary time consistent with the development of the placenta (Andersen et al. 2012; Samstein et al. 2012b).

An in vitro model of linked suppression, where a $\mathrm{CD}^{+}{ }^{+}$regulatory T-cell clone expressing constitutive CTLA4 was able to suppress the proliferation of a $\mathrm{CD} 8^{+}$CTL clone was also found to depend on the induction of IDO in a subset of dendritic APC (Mellor et al. 2004). In this case, it was shown that IDO acted specifically by depleting tryptophan from the medium, rather than generating potentially inhibitory kynurenines (Mezrich et al. 2010), as adding excess tryptophan could overcome the suppression. In a similar manner, it has been shown that Treg cells can induce in APC many different catabolic or synthetic enzymes that can deplete EAAs, including IDO, arginase, and iNOS (which can both use arginine), and IL4i1 (which depletes phenylalanine) (Cobbold et al. 2009). Histidine decarboxylase and tryptophan hydroxylase can be induced particularly in mast cells, and depletion of tryptophan by the latter enzyme (rather than its synthetic function of producing serotonin) has recently been shown to explain why mast cells seem to be required in some models of transplantation tolerance (Nowak et al. 2012). The healthy or healing tissue itself can also contribute to this EAA-depleted tolerogenic environment by expressing further catabolic enzymes for the branched chain amino acids and threonine (Cobbold et al. 2009).

The depletion of EAAs is sensed by T cells through two different pathways. One is known 
as the "integrated stress response," which relies on GCN2 detecting an excess of free tRNAs within the cell, and which is thought to be particularly important for detecting tryptophan depletion (Munn et al. 2005). Although it was initially thought that GCN2 signaling could inhibit proliferation and induce foxp3 and regulatory T-cell activity directly in the T cell, most evidence now suggests that it acts indirectly by modifying differentiation of the APC to a more tolerogenic phenotype (Sharma et al. 2007). The second amino acid-sensing pathway depends on the "ragulator" complex (Sancak et al. 2010; Zoncu et al. 2011), which acts via the RAG family of GTPases, and in the absence of amino acids this fails to recruit and activate the TORC1 complex via Rheb on the lysosomal membrane. This mode of sensing amino acid depletion can also be mimicked by the mTOR inhibitor rapamycin, which also acts to disrupt the TORC1 complex (Hara et al. 2002). Whereas rapamycin-mediated $\mathrm{mTOR}$ inhibition is also able to induce tolerogenic properties in dendritic cells (Taner et al. 2005), it can act directly on $\mathrm{T}$ cells to inhibit proliferation and to induce foxp3. Treg cells are also relatively resistant to mTOR inhibition, possibly as a result of the foxp3-mediated expression of PIM2 kinase that can promote T-cell survival in a manner independent of the PI3k/mTOR pathway (Basu et al. 2008).

Experiments in mice with specific defects in either TORC1 or TORC2 have suggested that both of these mTOR complexes need to be inhibited to enforce effective Treg differentiation (Delgoffe et al. 2009). Although rapamycin has usually been thought of as a specific inhibitor of TORC1, it is increasingly recognized that longer-term exposure to this inhibitor can also reduce TORC2 and downstream signaling through AKT (Barquilla et al. 2008). Even more recently, it has been shown that amino acids can actually activate both of the mTOR complexes (Tato et al. 2011). Although it is unclear how mTOR inhibition is linked to foxp3 expression, there is evidence that it may act, in part, via HIF $1 \alpha$ and the hypoxia-sensing pathway (Ben-Shoshan et al. 2008; Shi et al. 2011; Clambey et al. 2012).
It is intriguing that immunosuppressive drugs that can inhibit the mTOR pathway directly (e.g., rapamycin/sirolimus) or indirectly (e.g., fingolimod), and which should therefore promote Treg differentiation, are already being used in clinical practice. However, the proportion of patients who can be weaned off of continuous immunosuppression remains extremely low (Roussey-Kesler et al. 2006). It remains to be seen whether this situation can be improved as new induction protocols, such as T-cell depletion (Morgan et al. 2012), allow for minimization of other immunosuppressive agents that may counteract tolerance.

In summary, there may not be a single, unique mechanism of action by which Treg induce and maintain tolerance, but rather a complex set of interactions between Treg, APCs, and the tissue that generate a microenvironment (Fig. 2) that not only suppresses potential inflammatory responses but can also promote further Treg differentiation via linked suppression and infectious tolerance (Cobbold et al. 2006). One key feature of the tolerogenic microenvironment may be that it is compartmentalized from the inflammatory signals such as IL-6 (Yang et al. 2008) and complement activation (Kwan et al. 2012; Le Friec et al. 2012) that would otherwise compromise the stability of Treg and their further generation. Although infectious tolerance has mainly been considered a mechanism for foxp $3^{+}$Treg to generate a second foxp $3^{+}$iTreg cohort (Kendal et al. 2011), it remains unclear whether this is necessary or sufficient to maintain the tolerant state long term. In particular, it remains possible that IL-10-producing $\operatorname{Tr} 1$ cells may also play a role (Cobbold et al. 2003; Stassen et al. 2004).

\section{T-CELL-SUBSET-SPECIFIC REGULATION AND COEXPRESSION OF TRANSCRIPTION FACTORS}

Although Treg appear to act via many apparently parallel and potentially redundant mechanisms to inhibit almost the entire range of innate and adaptive immune responses, evidence of some specialization within subsets of foxp $3^{+}$ Treg is beginning to emerge. It seems that for 


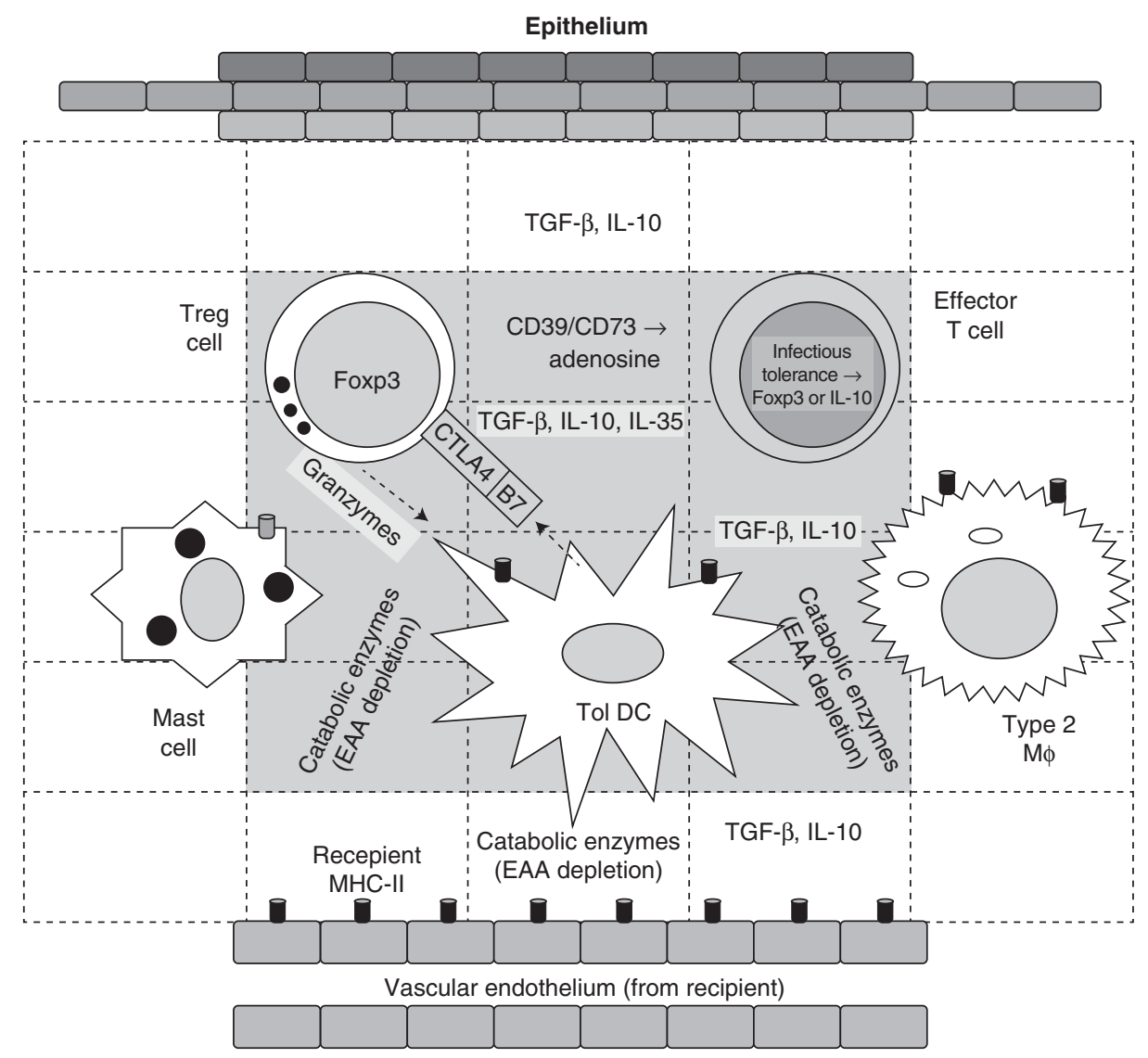

Figure 2. Treg cells act within tissue to create a state of induced immune privilege. A localized tolerogenic microenvironment is established in tolerated tissues by the interaction of foxp3 ${ }^{+}$Treg cells with cells capable of presenting antigen in the context of MHC-II. These MHC-II ${ }^{+}$-presenting cells, including dendritic cells (modulated to "TolDC"), macrophages (modulated to Type $2 \mathrm{M \phi}$ ), and mast cells both contribute to, and are modulated by, this tolerogenic microenvironment, which is maintained by the cytokines TGF- $\beta$, IL10, and IL-35, the CD39- and CD73-mediated conversion of ATP to adenosine, and the expression of multiple enzymes that deplete essential amino acids (EAAs). In addition, Treg cells may down-regulate antigen presentation by CTLA4-mediated trogocytosis of the costimulatory B7 ligands, or by granzyme-mediated killing of inflammatory/donor APCs. In this tolerogenic microenvironment, effector T cells may be "reprogrammed" to differentiate into Treg cells expressing foxp3 and/or IL-10 in a form of infectious tolerance.

Treg to suppress different functional T-cell subsets they need to co-express the appropriate associated transcription factors such as Tbet for suppression of Th1 (Koch et al. 2009) or GATA3 (Wang et al. 2011) and IRF4 to inhibit Th2 (Cretney et al. 2011). It is thought that direct molecular interactions between foxp 3 and these Th subset transcription factors in some way modifies the expression pattern of foxp3 target genes (Samstein et al. 2012a), perhaps to ensure that the appropriate Treg cell subset is engaged and will express appropriate chemokine and homing receptors to be able to localize to the same site as the effector cells, so ensuring efficient regulation at the site of inflammation (Wing and Sakaguchi 2012). There also seem to be a subset of foxp3 positive follicular Treg cells (Tfr cells) that inhibit antibody responses (Wollenberg et al. 2011), which like their foxp3 negative Tfh helper cell equivalents, express high 
S.P. Cobbold and H. Waldmann

levels of BCL6 and CXCR5, and are restricted to the B cell follicle (Chung et al. 2011; Linterman et al. 2011).

\section{MEMORY RESPONSES AND HETEROLOGOUS IMMUNITY}

Although foxp3-expressing Treg are able to control the initiation of all arms of the immune response, are they effective in the face of a memory response? This is particularly important in attempts to translate tolerogenic therapies to humans, where previous blood transfusions, pregnancy, and heterologous immunity from infections (Adams et al. 2003) and homeostatic expansion after T-cell depletion (Wu et al. 2004) can all generate memory to donor alloantigens. In addition, memory $\mathrm{T}$ cells have a different requirement for costimulation to naïve T cells (Markovic-Plese et al. 2001; Fuse et al. 2008), so therapeutic approaches using a costimulation blockade may be less effective ( $\mathrm{Wu}$ et al. 2004). We know, however, that one can induce tolerance in primed recipients (Cobbold et al. 1990; Marshall et al. 1996), and it seems that this is more a quantitative issue, where more Treg or additional immunosuppression are required to control the higher frequency of effector memory cells (Neujahr et al. 2006; Siepert et al. 2012).

\section{OTHER CELLS WITH REGULATORY ACTIVITY}

As we have seen, foxp $3^{+}$Treg cells function via the combined expression of many different molecular pathways, many of which can also be expressed on other, non-foxp3-expressing $\mathrm{T}$ cell subsets. It is therefore not surprising that a variety of non-foxp3-expressing $\mathrm{T}$ cells possess some regulatory activity. Activated $\mathrm{T}$ cells, for example, can express CTLA4 and, just like foxp $3^{+}$Treg, are able to capture costimulatory ligands by trogocytosis and down-regulate APC (Zhang et al. 2011). Similarly, as has been claimed for granzyme-expressing foxp $3^{+}$Treg cells, any cell capable of killing APC, including conventional CTL and NK cells (Cassell and Forman 1990), may be able to suppress the im- mune response, particular to directly presented alloantigens (He et al. 2007). TGF- $\beta$ is particularly produced by non-foxp3-expressing Th3 cells implicated in some models of oral tolerance (Fukaura et al. 1996), while IL-10 secretion is a characteristic feature of the foxp 3 negative $\operatorname{Tr} 1$ cell subset (Groux et al. 1997). And, like Treg, they can constitutively express CTLA4 (Zelenika et al. 2002; Mellor et al. 2004). Adoptive transfer of purified or cloned antigenspecific $\operatorname{Tr} 1$ cells can block the induction of inflammatory bowel disease in mice and seem to be as effective as foxp $3^{+}$Treg in suppressing allogeneic skin graft rejection (Zelenika et al. 2002). IL-10-secreting $\operatorname{Tr} 1$ cells also seem to play an important role in regulating allergic responses in humans (Akdis et al. 2004; Mobs et al. 2010) —with some of the best evidence coming from the studies of seasonal and reciprocal changes in cytokine-secreting T-cell subsets and in response to immunotherapy (McHugh et al. 1996; Fellrath et al. 2003).

Not all cells with regulatory activity are even T cells. As previously discussed, within tolerated grafts and healing self-tissues, many different migratory and tissue cells can respond by contributing components toward the local state of induced immune privilege. Dendritic cells and macrophages, for example, can differentiate, particularly in the presence of anti-inflammatory cytokines such as TGF- $\beta$ and IL-10, or in the presence of retinoic acid or vitamin D3 (Farquhar et al. 2010), into alternately activated states that preferentially present antigen for Treg differentiation (Gregori et al. 2001). In some transplantation models, it is possible to promote tolerance induction by the adoptive transfer of these syngenic "TolDC" to recipients of skin allografts, although this usually requires some additional immunosuppressive conditioning (Peche et al. 2005). Most recently, there has also been a surge in interest in a population of IL-10-producing "regulatory” B cells (Breg), which were shown to suppress inflammatory responses in various autoimmune disease models (Mauri and Ehrenstein 2008). B-cell-deficient $\mu$ MT mice, for example, develop a chronic form of experimental autoimmune encephalomyelitis (EAE) compared with the normally 
self-resolving acute inflammation seen in wildtype mice (Gonnella et al. 2001). Breg seem to be related to the $\mathrm{CD} 1 \mathrm{~d}^{+} \mathrm{CD} 5^{+}$Type 2 and marginal zone $\mathrm{B}$ cells often associated with autoreactivity (Lemoine et al. 2009), but their distinguishing feature seems to be the high levels of IL-10 secretion (Carter et al. 2012). In humans, increased frequencies of IL-10-expressing B cells are associated with a positive outcome in renal transplantation patients (Ranjbar et al. 2012). Although Breg cells may be able to induce FasL-mediated apoptosis of effector cells (Lundy 2009), it is thought that they act similarly to TolDC in presenting antigen, in this case in the context of IL-10, for the preferential induction of foxp $3^{+}$Treg cells (Kessel et al. 2012).

\section{REGULATORY GENES AS POTENTIAL BIOMARKERS OF TOLERANCE?}

A major problem for translating tolerogenicand Treg-based therapies to clinical transplantation is that there is no simple means to identify when tolerance to the donor graft has actually been achieved. This would facilitate any attempt to wean patients off of long-term immunosuppression. As foxp $3^{+}$Treg play such an important part in the induction and maintenance of transplantation tolerance in mouse models, one might expect that biomarkers of Treg and their activity might be useful surrogate indicators of the development of a tolerant state. This has proven not to be the case for a number of reasons (Cobbold et al. 2011). First, the most effective Treg have specificity for the donor antigen, so the overall frequency of foxp $3^{+}$Treg is not necessarily correlated with tolerance in mice with a normal TCR repertoire. In addition, antigenspecific Treg may be concentrated in the transplanted organ and poorly correlated with circulating Treg cell frequencies. Whereas graft biopsies might be useful to identify infiltrating Treg cells or the expression of genes associated with a tolerogenic microenvironment, these same processes appear to a large extent to overlap with the normal resolution of inflammation and healing and may therefore not be prognostic for the development of donor-specific tolerance. The only potential biomarker assays we currently have available are derived from gene expression studies in the very small number of patients who have managed to be weaned off immunosuppression and are therefore considered operationally tolerant of their graft (Newell et al. 2010; Sagoo et al. 2010; Brouard et al. 2011). These patterns of gene expression seem to be specific to the organ grafted, or perhaps the immunosuppressive protocol the patients were exposed to, as there seems to be no similarity between, for example, recipients of livers when compared with kidney transplant patients (Londono et al. 2012). Clinical trials to use these biomarkers as a guide to select patients for weaning are at too early a stage to evaluate.

\section{CONCLUDING REMARKS}

We are now beginning to understand from studies in animal models the importance of regulatory cells and their interactions with tissues in determining whether a graft is tolerated or rejected, but we are still struggling to successfully translate this knowledge to clinical transplantation. This is, in part, attributable to the remarkable success in developing combinations of immunosuppressive drugs that allow us to effectively control acute graft rejection, yet make it ethically difficult to move to alternative, as yet unproven, tolerogenic strategies. If Treg therapies are ever to be clinically applicable, their logistics must be amenable for commercial development, and this may limit their potential. If it were possible to use drugs and antibodies to potentiate Treg within the patient, then this might be within the realm of current pharmaceutical practice. However, until we more fully understand how Treg function to ensure tolerance in vivo, it will remain a considerable challenge to exploit all their complex properties for therapeutic benefit.

\section{REFERENCES}

Adams AB, Pearson TC, Larsen CP. 2003. Heterologous immunity: An overlooked barrier to tolerance. Immunol Rev 196: $147-160$.

Akdis M, Verhagen J, Taylor A, Karamloo F, Karagiannidis C, Crameri R, Thunberg S, Deniz G, Valenta R, Fiebig H, et al. 2004. Immune responses in healthy and allergic 
individuals are characterized by a fine balance between allergen-specific Tregulatory 1 and T helper 2 cells. J Exp Med 199: $1567-1575$.

Alyanakian MA, You S, Damotte D, Gouarin C, Esling A, Garcia C, Havouis S, Chatenoud L, Bach JF. 2003. Diversity of regulatory $\mathrm{CD} 4^{+} \mathrm{T}$ cells controlling distinct organspecific autoimmune diseases. Proc Natl Acad Sci 100: 15806-15811.

Andersen KG, Nissen JK, Betz AG. 2012. Comparative genomics reveals key gain-of-function events in Foxp3 during regulatory T cell evolution. Front Immunol 3: 113.

Asano M, Toda M, Sakaguchi N, Sakaguchi S. 1996. Autoimmune disease as a consequence of developmental abnormality of a T cell subpopulation. J Exp Med 184: 387-396.

Aschenbrenner K, D'Cruz LM, Vollmann EH, Hinterberger M, Emmerich J, Swee LK, Rolink A, Klein L. 2007. Selection of Foxp $3^{+}$regulatory T cells specific for self antigen expressed and presented by Aire ${ }^{+}$medullary thymic epithelial cells. Nat Immunol 8: 351-358.

Barquilla A, Crespo JL, Navarro M. 2008. Rapamycin inhibits trypanosome cell growth by preventing TOR complex 2 formation. Proc Natl Acad Sci 105: 14579-14584.

Basu S, Golovina T, Mikheeva T, June CH, Riley JL. 2008. Cutting edge: Foxp3-mediated induction of pim 2 allows human T regulatory cells to preferentially expand in rapamycin. J Immunol 180: 5794-5798.

Ben-Shoshan J, Maysel-Auslender S, Mor A, Keren G, George J. 2008. Hypoxia controls $\mathrm{CD} 4^{+} \mathrm{CD} 25^{+}$regulatory T-cell homeostasis via hypoxia-inducible factor- $1 \alpha$. Eur J Immunol 38: 2412-2418.

Beverly B, Kang SM, Lenardo MJ, Schwartz RH. 1992. Reversal of in vitro T cell clonal anergy by IL-2 stimulation. Int Immunol 4: 661-671.

Billingham RE, Brent L, Medawar PB. 1953. Actively acquired tolerance of foreign cells. Nature 172: 603-606.

Billingham RE, Brent L, Medawar PB. 1954. Quantitative studies on tissue transplantation immunity. II. The origin, strength and duration of actively and adoptively acquired immunity. Proc R Soc Lond B Biol Sci 143: 58-80.

Bopp T, Becker C, Klein M, Klein-Hessling S, Palmetshofer A, Serfling E, Heib V, Becker M, Kubach J, Schmitt S, et al. 2007. Cyclic adenosine monophosphate is a key component of regulatory $\mathrm{T}$ cell-mediated suppression. $J$ Exp Med 204: 1303-1310.

Brouard S, Le Bars A, Dufay A, Gosselin M, Foucher Y, Guillet M, Cesbron-Gautier A, Thervet E, Legendre C, Dugast E, et al. 2011. Identification of a gene expression profile associated with operational tolerance among a selected group of stable kidney transplant patients. Transpl Int 24: 536-547.

Carter NA, Rosser EC, Mauri C. 2012. Interleukin-10 produced by B cells is crucial for the suppression of Th17/ Th1 responses, induction of Tregulatory type 1 cells and reduction of collagen-induced arthritis. Arthritis Res Ther 14: R32.

Cassell DJ, Forman J. 1990. Regulation of the cytotoxic T lymphocyte response against Qa-1 alloantigens. J Immunol 144: 4075-4081.

Caudy AA, Reddy ST, Chatila T, Atkinson JP, Verbsky JW. 2007. CD25 deficiency causes an immune dysregulation, polyendocrinopathy, enteropathy, X-linked-like syndrome, and defective IL-10 expression from CD4 lymphocytes. J Allergy Clin Immunol 119: 482-487.

Chang JT, Palanivel VR, Kinjyo I, Schambach F, Intlekofer AM, Banerjee A, Longworth SA, Vinup KE, Mrass P, Oliaro J, et al. 2007. Asymmetric T lymphocyte division in the initiation of adaptive immune responses. Science 315: 1687-1691.

Chen W, Jin W, Hardegen N, Lei KJ, Li L, Marinos N, McGrady G, Wahl SM. 2003. Conversion of peripheral $\mathrm{CD} 4{ }^{+} \mathrm{CD} 25$ - naive $\mathrm{T}$ cells to $\mathrm{CD} 4^{+} \mathrm{CD} 25^{+}$regulatory $\mathrm{T}$ cells by TGF- $\beta$ induction of transcription factor Foxp3. J Exp Med 198: 1875-1886.

Chen TC, Cobbold SP, Fairchild PJ, Waldmann H. 2004. Generation of anergic and regulatory $\mathrm{T}$ cells following prolonged exposure to a harmless antigen. J Immunol 172: 5900-5907.

Chen LC, Delgado JC, Jensen PE, Chen X. 2009. Direct expansion of human allospecific FoxP $3{ }^{+} \mathrm{CD}^{+}$regulatory T cells with allogeneic B cells for therapeutic application. J Immunol 183: 4094-4102.

Chung Y, Tanaka S, Chu F, Nurieva RI, Martinez GJ, Rawal S, Wang YH, Lim H, Reynolds JM, Zhou XH, et al. 2011. Follicular regulatory T cells expressing Foxp3 and Bcl-6 suppress germinal center reactions. Nat Med 17: 983988.

Clambey ET, McNamee EN, Westrich JA, Glover LE, Campbell EL, Jedlicka P, de Zoeten EF, Cambier JC, Stenmark KR, Colgan SP, et al. 2012. Hypoxia-inducible factor- $1 \alpha$-dependent induction of FoxP3 drives regulatory T-cell abundance and function during inflammatory hypoxia of the mucosa. Proc Natl Acad Sci 109: E2784E2793.

Cobbold SP, Martin G, Qin S, Waldmann H. 1986. Monoclonal-antibodies to promote marrow engraftment and tissue graft tolerance. Nature 323: 164-166.

Cobbold SP, Martin G, Waldmann H. 1990. The induction of skin graft tolerance in major histocompatibility complex-mismatched or primed recipients: Primed T cells can be tolerized in the periphery with anti-CD4 and anti-CD8 antibodies. Eur J Immunol 20: 2747-2755.

Cobbold SP, Qin SX, Leong LYW, Martin G, Waldmann H. 1992. Reprogramming the immune-system for peripheral tolerance with $\mathrm{Cd} 4$ and $\mathrm{Cd} 8$ monoclonal-antibodies. Immunol Rev 129: 165-201.

Cobbold SP, Nolan KF, Graca L, Castejon R, Le Moine A, Frewin M, Humm S, Adams E, Thompson S, Zelenika D, et al. 2003. Regulatory T cells and dendritic cells in transplantation tolerance: molecular markers and mechanisms. Immunol Rev 196: 109-124.

Cobbold SP, Castejon R, Adams E, Zelenika D, Graca L, Humm S, Waldmann H. 2004. Induction of foxP3 ${ }^{+}$regulatory $\mathrm{T}$ cells in the periphery of $\mathrm{T}$ cell receptor transgenic mice tolerized to transplants. J Immunol 172: 6003-6010.

Cobbold SP, Adams E, Graca L, Daley S, Yates S, Paterson A, Robertson NJ, Nolan KF, Fairchild PJ, Waldmann H. 2006. Immune privilege induced by regulatory $\mathrm{T}$ cells in transplantation tolerance. Immunol Rev 213: 239-255.

Cobbold SP, Adams E, Farquhar CA, Nolan KF, Howie D, Lui KO, Fairchild PJ, Mellor AL, Ron D, Waldmann H. 2009. Infectious tolerance via the consumption of 
essential amino acids and mTOR signaling. Proc Natl Acad Sci 106: 12055-12060.

Cobbold SP, Adams E, Waldmann H. 2011. Biomarkers of transplantation tolerance: More hopeful than helpful? Front Immunol 2: 9.

Collison LW, Workman CJ, Kuo TT, Boyd K, Wang Y, Vignali KM, Cross R, Sehy D, Blumberg RS, Vignali DA. 2007. The inhibitory cytokine IL-35 contributes to regulatory T-cell function. Nature 450: 566-569.

Cone RE, Cochrane R, Lingenheld EG, Clark RB. 1996. Elevation of intracellular cyclic AMP induces an anergiclike state in Th1 clones. Cell Immunol 173: 246-251.

Cretney E, Xin A, Shi W, Minnich M, Masson F, Miasari M, Belz GT, Smyth GK, Busslinger M, Nutt SL, et al. 2011. The transcription factors Blimp-1 and IRF4 jointly control the differentiation and function of effector regulatory T cells. Nat Immunol 12: 304-311.

Daniel C, Wennhold K, Kim HJ, von Boehmer H. 2010. Enhancement of antigen-specific Treg vaccination in vivo. Proc Natl Acad Sci 107: 16246-16251.

Davies JD, Leong LYW, Mellor A, Cobbold SP, Waldmann H. 1996. T cell suppression in transplantation tolerance through linked recognition. J Immunol 156: 3602-3607.

Delgoffe GM, Kole TP, Zheng Y, Zarek PE, Matthews KL, Xiao B, Worley PF, Kozma SC, Powell JD. 2009. The mTOR kinase differentially regulates effector and regulatory T cell lineage commitment. Immunity 30: 832-844.

Earle KE, Tang Q, Zhou X, Liu W, Zhu S, Bonyhadi ML, Bluestone JA. 2005. In vitro expanded human $\mathrm{CD}^{+}$ $\mathrm{CD} 25^{+}$regulatory $\mathrm{T}$ cells suppress effector $\mathrm{T}$ cell proliferation. Clin Immunol 115: 3-9.

Edinger M, Hoffmann P, Ermann J, Drago K, Fathman CG, Strober S, Negrin RS. 2003. $\mathrm{CD} 4^{+} \mathrm{CD} 25^{+}$regulatory T cells preserve graft-versus-tumor activity while inhibiting graft-versus-host disease after bone marrow transplantation. Nat Med 9: 1144-1150.

Farquhar CA, Paterson AM, Cobbold SP, Garcia Rueda H, Fairchild PJ, Yates SF, Adams E, Saunders NJ, Waldmann H, Nolan KF. 2010. Tolerogenicity is not an absolute property of a dendritic cell. Eur J Immunol 40: $1728-1737$.

Fellrath JM, Kettner A, Dufour N, Frigerio C, Schneeberger D, Leimgruber A, Corradin G, Spertini F. 2003. Allergen-specific T-cell tolerance induction with allergen-derived long synthetic peptides: Results of a phase I trial. J Allergy Clin Immunol 111: 854-861.

Fitzgerald DC, Zhang GX, El-Behi M, Fonseca-Kelly Z, Li H, Yu S, Saris CJ, Gran B, Ciric B, Rostami A. 2007. Suppression of autoimmune inflammation of the central nervous system by interleukin 10 secreted by interleukin 27-stimulated T cells. Nat Immunol 8: 1372-1379.

Floess S, Freyer J, Siewert C, Baron U, Olek S, Polansky J, Schlawe K, Chang HD, Bopp T, Schmitt E, et al. 2007. Epigenetic control of the foxp3 locus in regulatory $\mathrm{T}$ cells. PLoS Biol 5: e38.

Fontenot JD, Gavin MA, Rudensky AY. 2003. Foxp3 programs the development and function of $\mathrm{CD} 4^{+} \mathrm{CD} 25^{+}$ regulatory T cells. Nat Immunol 4: 330-336.

Fu S, Yopp AC, Mao X, Chen D, Zhang N, Chen D, Mao M, Ding Y, Bromberg JS. 2004. CD $4^{+} \mathrm{CD} 25^{+} \mathrm{CD} 62^{+}$T-reg- ulatory cell subset has optimal suppressive and proliferative potential. Am J Transplant 4: 65-78.

Fukaura H, Kent SC, Pietrusewicz MJ, Khoury SJ, Weiner HL, Hafler DA. 1996. Induction of circulating myelin basic protein and proteolipid protein-specific transforming growth factor- $\beta 1$-secreting Th $3 \mathrm{~T}$ cells by oral administration of myelin in multiple sclerosis patients. J Clin Invest 98: 70-77.

Fuse S, Zhang W, Usherwood EJ. 2008. Control of memory $\mathrm{CD}^{+} \mathrm{T}$ cell differentiation by CD80/CD86-CD28 costimulation and restoration by IL-2 during the recall response. J Immunol 180: 1148-1157.

Gershon RK, Kondo K. 1971. Infectious immunological tolerance. Immunology 21: 903-914.

Gonnella PA, Waldner HP, Weiner HL. 2001. B cell-deficient $(\mu \mathrm{MT})$ mice have alterations in the cytokine microenvironment of the gut-associated lymphoid tissue (GALT) and a defect in the low dose mechanism of oral tolerance. J Immunol 166: 4456-4464.

Graca L, Cobbold SP, Waldmann H. 2002. Identification of regulatory $\mathrm{T}$ cells in tolerated allografts. J Exp Med 195: 1641-1646.

Graca L, Le Moine A, Lin CY, Fairchild PJ, Cobbold SP, Waldmann H. 2004. Donor-specific transplantation tolerance: The paradoxical behavior of $\mathrm{CD} 4{ }^{+} \mathrm{CD} 25^{+}$ T cells. Proc Natl Acad Sci 101: 10122-10126.

Gregori S, Casorati M, Amuchastegui S, Smiroldo S, Davalli AM, Adorini L. 2001. Regulatory T cells induced by $1 \alpha, 25$-dihydroxyvitamin D3 and mycophenolate mofetil treatment mediate transplantation tolerance. J Immunol 167: 1945-1953.

Groux H, O'Garra A, Bigler M, Rouleau M, Antonenko S, de Vries JE, Roncarolo MG. 1997. A CD4 ${ }^{+}$T-cell subset inhibits antigen-specific T-cell responses and prevents colitis. Nature 389: 737-742.

Hale G, Waldmann H. 1996. Recent results using CAMPATH-1 antibodies to control GVHD and graft rejection. Bone Marrow Transplant 17: 305-308.

Hall BM. 1985. Mechanisms maintaining enhancement of allografts. I. Demonstration of a specific suppressor cell. J Exp Med 161: 123-133.

Hara K, Maruki Y, Long X, Yoshino K, Oshiro N, Hidayat S, Tokunaga C, Avruch J, Yonezawa K. 2002. Raptor, a binding partner of target of rapamycin (TOR), mediates TOR action. Cell 110: 177-189.

He KM, Ma Y, Wang S, Min WP, Zhong R, Jevnikar A, Zhang ZX. 2007. Donor double-negative Treg promote allogeneic mixed chimerism and tolerance. Eur J Immunol 37: 3455-3466.

Horak I, Lohler J, Ma A, Smith KA. 1995. Interleukin-2 deficient mice: A new model to study autoimmunity and self-tolerance. Immunol Rev 148: 35-44.

Hori S, Nomura T, Sakaguchi S. 2003. Control of regulatory $\mathrm{T}$ cell development by the transcription factor Foxp3. Science 299: 1057-1061.

Jiang S, Herrera O, Lechler RI. 2004. New spectrum of allorecognition pathways: Implications for graft rejection and transplantation tolerance. Curr Opin Immunol 16: 550557.

Kendal AR, Chen Y, Regateiro FS, Ma JB, Adams E, Cobbold SP, Hori S, Waldmann H. 2011. Sustained 
suppression by Foxp $3^{+}$regulatory T cells is vital for infectious transplantation tolerance. $J$ Exp Med 208: 2043-2053.

Kessel A, Haj T, Peri R, Snir A, Melamed D, Sabo E, Toubi E. 2012. Human $\mathrm{CD} 19^{+} \mathrm{CD} 25^{\text {high }} \mathrm{B}$ regulatory cells suppress proliferation of $\mathrm{CD}^{+} \mathrm{T}$ cells and enhance Foxp3 and CTLA-4 expression in T-regulatory cells. Autoimmun Rev 11: 670-677.

Khattri R, Cox T, Yasayko SA, Ramsdell F. 2003. An essential role for Scurfin in $\mathrm{CD} 4^{+} \mathrm{CD} 25^{+}$T regulatory cells. Nat Immunol 4: 337-342.

Koch MA, Tucker-Heard G, Perdue NR, Killebrew JR, Urdahl KB, Campbell DJ. 2009. The transcription factor T-bet controls regulatory $\mathrm{T}$ cell homeostasis and function during type 1 inflammation. Nat Immunol 10: 595-602.

Kramer S, Schimpl A, Hunig T. 1995. Immunopathology of interleukin IL-2-deficient mice: Thymus dependence and suppression by thymus-dependent cells with an intact IL-2 gene. J Exp Med 182: 1769-1776.

Kretschmer K, Apostolou I, Hawiger D, Khazaie K, Nussenzweig MC, von Boehmer H. 2005. Inducing and expanding regulatory $\mathrm{T}$ cell populations by foreign antigen. Nat Immunol 6: 1219-1227.

Kwan WH, van der Touw W, Heeger PS. 2012. Complement regulation of T cell immunity. Immunol Res 54: 247-253.

Lal G, Zhang N, van der Touw W, Ding Y, Ju W, Bottinger EP, Reid SP, Levy DE, Bromberg JS. 2009. Epigenetic regulation of Foxp3 expression in regulatory T cells by DNA methylation. J Immunol 182: 259-273.

Le Friec G, Sheppard D, Whiteman P, Karsten CM, Shamoun SA, Laing A, Bugeon L, Dallman MJ, Melchionna T, Chillakuri C, et al. 2012. The CD46-Jagged1 interaction is critical for human TH1 immunity. Nat Immunol 13: 1213-1221.

Lee HM, Bautista JL, Scott-Browne J, Mohan JF, Hsieh CS. 2012. A broad range of self-reactivity drives thymic regulatory $\mathrm{T}$ cell selection to limit responses to self. Immunity 37: 475-486.

Lemoine S, Morva A, Youinou P, Jamin C. 2009. Regulatory B cells in autoimmune diseases: How do they work? Ann NYAcad Sci 1173: 260-267.

Leong LYW, Qin SX, Cobbold SP, Waldmann H. 1992. Classical transplantation tolerance in the adult- the interaction between myeloablation and immunosuppression. Eur J Immunol 22: 2825-2830.

Letourneau S, van Leeuwen EM, Krieg C, Martin C, Pantaleo G, Sprent J, Surh CD, Boyman O. 2010. IL-2/ anti-IL-2 antibody complexes show strong biological activity by avoiding interaction with IL-2 receptor $\alpha$ subunit CD25. Proc Natl Acad Sci 107: 2171-2176.

Linterman MA, Pierson W, Lee SK, Kallies A, Kawamoto S, Rayner TF, Srivastava M, Divekar DP, Beaton L, Hogan JJ, et al. 2011. Foxp $3^{+}$follicular regulatory $\mathrm{T}$ cells control the germinal center response. Nat Med 17: 975-982.

Liu WH, Putnam AL, Xu-Yu Z, Szot GL, Lee MR, Zhu S, Gottlieb PA, Kapranov P, Gingeras TR, Fazekas de St Groth B, et al. 2006. CD127 expression inversely correlates with FoxP3 and suppressive function of human $\mathrm{CD}^{+}{ }^{+}$T reg cells. J Exp Med 203: 1701-1711.

Londono MC, Danger R, Giral M, Soulillou JP, SanchezFueyo A, Brouard S. 2012. A need for biomarkers of operational tolerance in liver and kidney transplantation. Am J Transplant 12: 1370-1377.

Lu LF, Lind EF, Gondek DC, Bennett KA, Gleeson MW, Pino-Lagos K, Scott ZA, Coyle AJ, Reed JL, Van Snick J, et al. 2006. Mast cells are essential intermediaries in regulatory T-cell tolerance. Nature 442: 997-1002.

Lundy SK. 2009. Killer B lymphocytes: The evidence and the potential. Inflam Res 58: 345-357.

Markovic-Plese S, Cortese I, Wandinger KP, McFarland HF, Martin R. 2001. $\mathrm{CD}^{+} \mathrm{CD} 28^{-}$costimulation-independent $\mathrm{T}$ cells in multiple sclerosis. J Clin Invest 108: $1185-1194$.

Marshall SE, Cobbold SP, Davies JD, Martin GM, Phillips JM, Waldmann H. 1996. Tolerance and suppression in a primed immune system. Transplantation 62: 16141621.

Mauri C, Ehrenstein MR. 2008. The "short" history of regulatory B cells. Trends Immunol 29: 34-40.

Mauri C, Gray D, Mushtaq N, Londei M. 2003. Prevention of arthritis by interleukin 10-producing B cells. J Exp Med 197: 489-501.

McClymont SA, Putnam AL, Lee MR, Esensten JH, Liu WH, Hulme MA, Hoffmuller U, Baron U, Olek S, Bluestone JA, et al. 2011. Plasticity of human regulatory $t$ cells in healthy subjects and patients with type 1 diabetes. $J$ Immunol 186: 3918-3926.

McHugh S, Deighton J, Rifkin I, Ewan P. 1996. Kinetics and functional implications of Th1 and Th2 cytokine production following activation of peripheral blood mononuclear cells in primary culture. Eur J Immunol 26: 1260 1265.

Mellor AL, Chandler P, Baban B, Hansen AM, Marshall B, Pihkala J, Waldmann H, Cobbold S, Adams E, Munn DH. 2004. Specific subsets of murine dendritic cells acquire potent T cell regulatory functions following CTLA4-mediated induction of indoleamine 2,3 dioxygenase. Int Immunol 16: 1391-1401.

Mezrich JD, Fechner JH, Zhang X, Johnson BP, Burlingham WJ, Bradfield CA. 2010. An interaction between kynurenine and the aryl hydrocarbon receptor can generate regulatory T cells. J Immunol 185: 3190-3198.

Mobs C, Slotosch C, Loffler H, Jakob T, Hertl M, Pfutzner W. 2010. Birch pollen immunotherapy leads to differential induction of regulatory $\mathrm{T}$ cells and delayed helper T cell immune deviation. J Immunol 184: 2194-2203.

Morgan RD, O’Callaghan JM, Knight SR, Morris PJ. 2012. Alemtuzumab induction therapy in kidney transplantation: A systematic review and meta-analysis. Transplantation 93: 1179-1188.

Munn DH, Zhou M, Attwood JT, Bondarev I, Conway SJ, Marshall B, Brown C, Mellor AL. 1998. Prevention of allogeneic fetal rejection by tryptophan catabolism. Science 281: 1191-1193.

Munn DH, Sharma MD, Baban B, Harding HP, Zhang Y, Ron D, Mellor AL. 2005. GCN2 kinase in T cells mediates proliferative arrest and anergy induction in response to indoleamine 2,3-dioxygenase. Immunity 22: 633-642.

Nakamura K, Kitani A, Strober W. 2001. Cell contact-dependent immunosuppression by $\mathrm{CD} 4{ }^{+} \mathrm{CD} 25^{+}$regulatory $\mathrm{T}$ cells is mediated by cell surface-bound transforming growth factor $\beta$. J Exp Med 194: 629-644. 
Nakamura K, Kitani A, Fuss I, Pedersen A, Harada N, Nawata H, Strober W. 2004. TGF- $\beta 1$ plays an important role in the mechanism of $\mathrm{CD} 4^{+} \mathrm{CD} 25^{+}$regulatory $\mathrm{T}$ cell activity in both humans and mice. J Immunol 172: 834-842.

Neujahr DC, Chen CQ, Huang X, Markmann JF, Cobbold S, Waldmann H, Sayegh MH, Hancock WW, Turka LA. 2006. Accelerated memory cell homeostasis during T cell depletion and approaches to overcome it. J Immuno 176: $4632-4639$.

Neumuller RA, Knoblich JA. 2009. Dividing cellular asymmetry: Asymmetric cell division and its implications for stem cells and cancer. Genes Dev 23: 2675-2699.

Newell KA, Asare A, Kirk AD, Gisler TD, Bourcier K, Suthanthiran M, Burlingham WJ, Marks WH, Sanz I, Lechler RI, et al. 2010. Identification of a B cell signature associated with renal transplant tolerance in humans. $J$ Clin Invest 120: 1836-1847.

Nowak EC, de Vries VC, Wasiuk A, Ahonen C, Bennett KA, Le Mercier I, Ha DG, Noelle RJ. 2012. Tryptophan hydroxylase-1 regulates immune tolerance and inflammation. J Exp Med 209: 2127-2135.

Ohkura N, Hamaguchi M, Morikawa H, Sugimura K, Tanaka A, Ito Y, Osaki M, Tanaka Y, Yamashita R, Nakano N, et al. 2012. T cell receptor stimulation-induced epigenetic changes and foxp3 expression are independent and complementary events required for treg cell development. Immunity 37: 785-799.

Paidassi H, Acharya M, Lacy-Hulbert A. 2010. $\alpha$ (v) Integrins license regulatory $\mathrm{T}$ cells to apoptotic cells and selfassociated antigens. Ann NY Acad Sci 1209: 68-76.

Paidassi H, Acharya M, Zhang A, Mukhopadhyay S, Kwon M, Chow C, Stuart LM, Savill J, Lacy-Hulbert A. 2011. Preferential expression of integrin $\alpha v \beta 8$ promotes generation of regulatory T cells by mouse $\mathrm{CD} 103^{+}$dendritic cells. Gastroenterology 141: 1813-1820.

Park HB, Paik DJ, Jang E, Hong S, Youn J. 2004. Acquisition of anergic and suppressive activities in transforming growth factor- $\beta$-costimulated $\mathrm{CD} 4^{+} \mathrm{CD} 25^{-} \mathrm{T}$ cells. Int Immunol 16: 1203-1213.

Peche H, Trinite B, Martinet B, Cuturi MC. 2005. Prolongation of heart allograft survival by immature dendritic cells generated from recipient type bone marrow progenitors. Am J Transplant 5: 255-267.

Powell JD, Lerner CG, Ewoldt GR, Schwartz RH. 1999. The -180 site of the IL-2 promoter is the target of CREB/ CREM binding in T cell anergy. J Immunol 163: 66316639.

Powrie F, Correa-Oliveira R, Mauze S, Coffman RL. 1994. Regulatory interactions between $\mathrm{CD} 45 \mathrm{RB}^{\text {high }}$ and $\mathrm{CD}_{45 \mathrm{RB}}{ }^{\text {low }} \mathrm{CD}^{+} \mathrm{T}$ cells are important for the balance between protective and pathogenic cell-mediated immunity. J Exp Med 179: 589-600.

Qin SX, Cobbold S, Benjamin R, Waldmann H. 1989. Induction of classical transplantation tolerance in the adult. J Exp Med 169: 779-794.

Qin SX, Wise M, Cobbold SP, Leong L, Kong YCM, Parnes JR, Waldmann H. 1990. Induction of tolerance in peripheral T-cells with monoclonal-antibodies. Eur J Immunol 20: 2737-2745.
Qin SX, Cobbold SP, Pope H, Elliott J, Kioussis D, Davies J, Waldmann H. 1993. Infectious transplantation tolerance. Science 259: 974-977.

Qureshi OS, Zheng Y, Nakamura K, Attridge K, Manzotti C, Schmidt EM, Baker J, Jeffery LE, Kaur S, Briggs Z, et al. 2011. Trans-endocytosis of CD80 and CD86: A molecular basis for the cell-extrinsic function of CTLA-4. Science 332: $600-603$.

Ranjbar M, Solgi G, Mohammadnia M, Nikbin B, Pourmand G, Ansaripour B, Amirzargar A. 2012. Regulatory T-cell subset analysis and profile of interleukin (IL)-10 IL-17 and interferon- $\gamma$ cytokine-producing cells in kidney allograft recipients with donor cells infusion. Clin Exp Nephrol 16: 636-646.

Regateiro FS, Howie D, Nolan KF, Agorogiannis EI, Greaves DR, Cobbold SP, Waldmann H. 2011. Generation of antiinflammatory adenosine by leukocytes is regulated by TGF- $\beta$. Eur J Immunol 41: 2955-2965.

Regateiro FS, Chen Y, Kendal AR, Hilbrands R, Adams E, Cobbold SP, Ma JB, Andersen KG, Betz AG, Zhang M, et al. 2012. Foxp3 expression is required for the induction of therapeutic tissue tolerance. J Immunol 189: 39473956.

Regateiro FS, Cobbold SP, Waldmann H. 2013. CD73 and adenosine generation in the creation of regulatory microenvironments. Clin Exp Immunol 171: 1-7.

Roussey-Kesler G, Giral M, Moreau A, Subra JF, Legendre C, Noel C, Pillebout E, Brouard S, Soulillou JP. 2006. Clinical operational tolerance after kidney transplantation. Am J Transplant 6: 736-746.

Rubtsov YP, Niec RE, Josefowicz S, Li L, Darce J, Mathis D, Benoist C, Rudensky AY. 2010. Stability of the regulatory $\mathrm{T}$ cell lineage in vivo. Science 329: 1667-1671.

Sagoo P, Perucha E, Sawitzki B, Tomiuk S, Stephens DA Miqueu P, Chapman S, Craciun L, Sergeant R, Brouard S, et al. 2010. Development of a cross-platform biomarker signature to detect renal transplant tolerance in humans. J Clin Invest 120: 1848-1861.

Samstein RM, Arvey A, Josefowicz SZ, Peng X, Reynolds A, Sandstrom R, Neph S, Sabo P, Kim JM, Liao W, et al. 2012a. Foxp3 exploits a pre-existent enhancer landscape for regulatory T cell lineage specification. Cell 151: 153166.

Samstein RM, Josefowicz SZ, Arvey A, Treuting PM, Rudensky AY. 2012b. Extrathymic generation of regulatory $\mathrm{T}$ cells in placental mammals mitigates maternalfetal conflict. Cell 150: 29-38.

Sancak Y, Bar-Peled L, Zoncu R, Markhard AL, Nada S, Sabatini DM. 2010. Ragulator-Rag complex targets mTORC1 to the lysosomal surface and is necessary for its activation by amino acids. Cell 141: 290-303.

Sanchez-Fueyo A, Domenig CM, Mariat C, Alexopoulos S, Zheng XX, Strom TB. 2007. Influence of direct and indirect allorecognition pathways on $\mathrm{CD} 4{ }^{+} \mathrm{CD} 25^{+}$regulatory T-cell function in transplantation. Transpl Int 20: $534-541$.

Sato K, Yamashita N, Yamashita N, Baba M, Matsuyama T. 2003. Regulatory dendritic cells protect mice from murine acute graft-versus-host disease and leukemia relapse. Immunity 18: 367-379.

Schwartz RH. 1990. A cell culture model for T lymphocyte clonal anergy. Science 248: 1349-1356. 
Scully R, Qin SX, Cobbold S, Waldmann H. 1994. Mechanisms in Cd4 antibody-mediated transplantation tolerance-Kinetics of induction, antigen dependency and role of regulatory T-cells. Eur J Immunol 24: 2383-2392.

Setoguchi R, Hori S, Takahashi T, Sakaguchi S. 2005. Homeostatic maintenance of natural Foxp $3^{+} \mathrm{CD} 25^{+} \mathrm{CD} 4^{+}$ regulatory $\mathrm{T}$ cells by interleukin IL-2 and induction of autoimmune disease by IL-2 neutralization. J Exp Med 201: 723-735.

Shah AH, Tabayoyong WB, Kimm SY, Kim SJ, Van Parijs L, Lee C. 2002. Reconstitution of lethally irradiated adult mice with dominant negative TGF- $\beta$ type II receptortransduced bone marrow leads to myeloid expansion and inflammatory disease. J Immunol 169: 3485-3491.

Sharma MD, Baban B, Chandler P, Hou DY, Singh N, Yagita H, Azuma M, Blazar BR, Mellor AL, Munn DH. 2007. Plasmacytoid dendritic cells from mouse tumordraining lymph nodes directly activate mature Tregs via indoleamine 2,3-dioxygenase. J Clin Invest 117: $2570-$ 2582.

Shevach EM. 2009. Mechanisms of foxp $3^{+}$Tregulatory cellmediated suppression. Immunity 30: 636-645.

Shevach EM, DiPaolo RA, Andersson J, Zhao DM, Stephens GL, Thornton AM. 2006. The lifestyle of naturally occurring $\mathrm{CD}^{+}{ }^{+} \mathrm{CD} 25^{+} \mathrm{Foxp}^{+}$regulatory $\mathrm{T}$ cells. Immunol Rev 212: 60-73.

Shi LZ, Wang R, Huang G, Vogel P, Neale G, Green DR, Chi H. 2011. HIF1 $\alpha$-dependent glycolytic pathway orchestrates a metabolic checkpoint for the differentiation of TH17 and Treg cells. J Exp Med 208: 1367-1376.

Shull MM, Ormsby I, Kier AB, Pawlowski S, Diebold RJ, Yin M, Allen R, Sidman C, Proetzel G, Calvin D, et al. 1992. Targeted disruption of the mouse transforming growth factor- $\beta 1$ gene results in multifocal inflammatory disease. Nature 359: 693-699.

Siepert A, Ahrlich S, Vogt K, Appelt C, Stanko K, Kuhl A, van den Brandt J, Reichardt HM, Nizze H, Lehmann M, et al. 2012. Permanent CNI treatment for prevention of renal allograft rejection in sensitized hosts can be replaced by regulatory T cells. Am J Transplant 12: 2384-2394.

Sojka DK, Hughson A, Fowell DJ. 2009. CTLA-4 is required by $\mathrm{CD} 4^{+} \mathrm{CD} 25^{+}$Treg to control $\mathrm{CD} 4^{+}$T-cell lymphopenia-induced proliferation. Eur J Immunol 39: 1544-1551.

Stassen M, Fondel S, Bopp T, Richter C, Muller C, Kubach J, Becker C, Knop J, Enk AH, Schmitt S, et al. 2004. Human $\mathrm{CD} 25^{+}$regulatory $\mathrm{T}$ cells: Two subsets defined by the integrins $\alpha 4 \beta 7$ or $\alpha 4 \beta 1$ confer distinct suppressive properties upon $\mathrm{CD}^{+} \mathrm{T}$ helper cells. Eur J Immunol 34: $1303-1311$.

Streilein JW, Gruchalla RS. 1981. Analysis of neonatally induced tolerance of $\mathrm{H}-2$ alloantigens. I. Adoptive transfer indicates that tolerance of class I and class II antigens is maintained by distinct mechanisms. Immunogenetics 12: $161-173$.

Sundstedt A, O’Neill EJ, Nicolson KS, Wraith DC. 2003. Role for IL-10 in suppression mediated by peptideinduced regulatory $\mathrm{T}$ cells in vivo. J Immunol 170: 1240-1248.

Takahashi H, Kanno T, Nakayamada S, Hirahara K, Sciume G, Muljo SA, Kuchen S, Casellas R, Wei L, Kanno Y et al. 2012. TGF- $\beta$ and retinoic acid induce the micro-
RNA miR-10a, which targets Bcl-6 and constrains the plasticity of helper T cells. Nat Immunol 13: 587-595.

Taner T, Hackstein H, Wang Z, Morelli AE, Thomson AW. 2005. Rapamycin-treated, alloantigen-pulsed host dendritic cells induce ag-specific $T$ cell regulation and prolong graft survival. Am J Transplant 5: 228-236.

Tato I, Bartrons R, Ventura F, Rosa JL. 2011. Amino acids activate mammalian target of rapamycin complex 2 (mTORC2) via PI3K/Akt signaling. J Biol Chem 286: 6128-6142.

Thornton AM, Korty PE, Tran DQ, Wohlfert EA, Murray PE, Belkaid Y, Shevach EM. 2010. Expression of Helios, an Ikaros transcription factor family member, differentiates thymic-derived from peripherally induced Foxp $3^{+}$T regulatory cells. J Immunol 184: 3433-3441.

Tivol EA, Borriello F, Schweitzer AN, Lynch WP, Bluestone JA, Sharpe AH. 1995. Loss of CTLA-4 leads to massive lymphoproliferation and fatal multiorgan tissue destruction, revealing a critical negative regulatory role of CTLA-4. Immunity 3: 541-547.

Tran DQ, Andersson J, Wang R, Ramsey H, Unutmaz D, Shevach EM. 2009. GARP (LRRC32) is essential for the surface expression of latent TGF- $\beta$ on platelets and activated FOXP $3^{+}$regulatory T cells. Proc Natl Acad Sci 106: $13445-13450$.

Trenado A, Charlotte F, Fisson S, Yagello M, Klatzmann D, Salomon BL, Cohen JL. 2003. Recipient-type specific $\mathrm{CD} 4{ }^{+} \mathrm{CD} 25^{+}$regulatory $\mathrm{T}$ cells favor immune reconstitution and control graft-versus-host disease while maintaining graft-versus-leukemia. J Clin Invest 112: $1688-1696$.

Tsang JY, Tanriver Y, Jiang S, Leung E, Ratnasothy K, Lombardi G, Lechler R. 2009. Indefinite mouse heart allograft survival in recipient treated with $\mathrm{CD} 4{ }^{+} \mathrm{CD} 25^{+}$ regulatory $\mathrm{T}$ cells with indirect allospecificity and short term immunosuppression. Transpl Immunol 21: 203209.

Uhlig HH, Coombes J, Mottet C, Izcue A, Thompson C, Fanger A, Tannapfel A, Fontenot JD, Ramsdell F, Powrie F. 2006. Characterization of Foxp $3^{+} \mathrm{CD} 4^{+} \mathrm{CD} 25^{+}$and IL-10-secreting $\mathrm{CD} 4^{+} \mathrm{CD} 25^{+}$T cells during cure of colitis. J Immunol 177: 5852-5860.

Veerapathran A, Pidala J, Beato F, Yu XZ, Anasetti C. 2011. Ex vivo expansion of human Tregs specific for alloantigens presented directly or indirectly. Blood 118: 56715680.

Wang J, Ioan-Facsinay A, van der Voort EI, Huizinga TW, Toes RE. 2007. Transient expression of FOXP3 in human activated nonregulatory $\mathrm{CD} 4^{+}$T cells. Eur J Immunol 37: 129-138.

Wang Y, Su MA, Wan YY. 2011. An essential role of the transcription factor GATA-3 for the function of regulatory T cells. Immunity 35: $337-348$.

Whitehead GS, Wilson RH, Nakano K, Burch LH, Nakano H, Cook DN. 2012. IL-35 production by inducible costimulator (ICOS)-positive regulatory $\mathrm{T}$ cells reverses established IL-17-dependent allergic airways disease. J Allergy Clin Immunol 129: 207-215.

Wing JB, Sakaguchi S. 2012. Multiple treg suppressive modules and their adaptability. Front Immunol 3: 178.

Wollenberg I, Agua-Doce A, Hernandez A, Almeida C, Oliveira VG, Faro J, Graca L. 2011. Regulation of the 
Regulatory T Cells

germinal center reaction by Foxp $3^{+}$follicular regulatory T cells. J Immunol 187: 4553-4560.

Wu Z, Bensinger SJ, Zhang J, Chen C, Yuan X, Huang X, Markmann JF, Kassaee A, Rosengard BR, Hancock WW, et al. 2004. Homeostatic proliferation is a barrier to transplantation tolerance. Nat Med 10: 87-92.

Yadav M, Louvet C, Davini D, Gardner JM, MartinezLlordella M, Bailey-Bucktrout S, Anthony BA, Sverdrup FM, Head R, Kuster DJ, et al. 2012. Neuropilin-1 distinguishes natural and inducible regulatory $\mathrm{T}$ cells among regulatory $\mathrm{T}$ cell subsets in vivo. J Exp Med 209: $1713-1722$.

Yang XO, Nurieva R, Martinez GJ, Kang HS, Chung Y, Pappu BP, Shah B, Chang SH, Schluns KS, Watowich SS, et al. 2008. Molecular antagonism and plasticity of regulatory and inflammatory T cell programs. Immunity 29: 44-56.

Yu P, Gregg RK, Bell JJ, Ellis JS, Divekar R, Lee HH, Jain R, Waldner H, Hardaway JC, Collins M, et al. 2005. Specific $\mathrm{T}$ regulatory cells display broad suppressive functions against experimental allergic encephalomyelitis upon activation with cognate antigen. J Immunol 174: 6772 6780.

Yurchenko E, Shio MT, Huang TC, Da Silva Martins M, Szyf M, Levings MK, Olivier M, Piccirillo CA. 2012. Inflammation-driven reprogramming of $\mathrm{CD}^{+}{ }^{+}$Foxp $3^{+}$ regulatory $\mathrm{T}$ cells into pathogenic Th1/Th17 T effectors is abrogated by mTOR inhibition in vivo. PloS ONE 7: e35572.

Zelenika D, Adams E, Humm S, Graca L, Thompson S, Cobbold SP, Waldmann H. 2002. Regulatory T cells overexpress a subset of Th2 gene transcripts. J Immunol 168: 1069-1079.

Zhang L, Gu P, Gao JF, Kowalczyk A, D'Souza CA, Chou KY. 2011. Trogocytosis of CD80 and CD86 by induced regulatory T cells. Am J Transplant 11: 187-188.

Zheng Y, Josefowicz S, Chaudhry A, Peng XP, Forbush K, Rudensky AY. 2010. Role of conserved non-coding DNA elements in the Foxp3 gene in regulatory T-cell fate. $\mathrm{Na}$ ture 463: 808-812.

Zhou X, Bailey-Bucktrout S, Jeker LT, Bluestone JA. 2009. Plasticity of $\mathrm{CD}^{+} \mathrm{FoxP}^{+} \mathrm{T}$ cells. Curr Opin Immunol 21: 281-285.

Zhou X, Kong N, Wang J, Fan H, Zou H, Horwitz D, Brand D, Liu Z, Zheng SG. 2010. Cutting edge: All-trans retinoic acid sustains the stability and function of natural regulatory $\mathrm{T}$ cells in an inflammatory milieu. J Immunol 185: 2675-2679.

Zoncu R, Bar-Peled L, Efeyan A, Wang S, Sancak Y, Sabatini DM. 2011. mTORC1 senses lysosomal amino acids through an inside-out mechanism that requires the vacuolar $\mathrm{H}^{+}$-ATPase. Science 334: 678-683. 


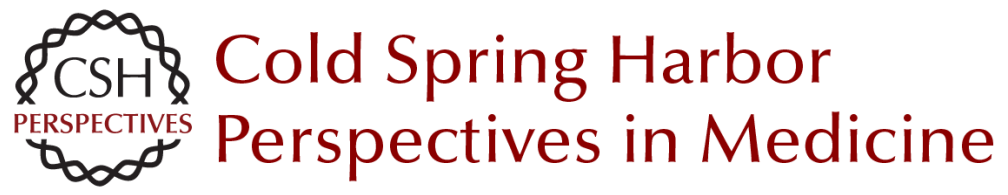

\section{Regulatory Cells and Transplantation Tolerance}

Stephen P. Cobbold and Herman Waldmann

Cold Spring Harb Perspect Med 2013; doi: 10.1101/cshperspect.a015545

Subject Collection Transplantation

Heart Transplantation: Challenges Facing the Field

Makoto Tonsho, Sebastian Michel, Zain Ahmed, et al.

Bioethics of Organ Transplantation Arthur Caplan

Overview of Clinical Lung Transplantation Jonathan C. Yeung and Shaf Keshavjee

Immunological Challenges and Therapies in

Xenotransplantation Marta Vadori and Emanuele Cozzi

Clinical Aspects: Focusing on Key Unique Organ-Specific Issues of Renal Transplantation Sindhu Chandran and Flavio Vincenti

T-Cell Costimulatory Blockade in Organ

Transplantation Jonathan S. Maltzman and Laurence A. Turka

Regulatory T-Cell Therapy in Transplantation: Moving to the Clinic

Qizhi Tang and Jeffrey A. Bluestone

Opportunistic Infections--Coming to the Limits of Immunosuppression?

Jay A. Fishman
Overview of the Indications and Contraindications for Liver Transplantation

Stefan Farkas, Christina Hackl and Hans Jürgen Schlitt

Facial and Hand Allotransplantation Bohdan Pomahac, Ryan M. Gobble and Stefan Schneeberger

Induction of Tolerance through Mixed Chimerism David H. Sachs, Tatsuo Kawai and Megan Sykes

Pancreas Transplantation: Solid Organ and Islet Shruti Mittal, Paul Johnson and Peter Friend

Tolerance--Is It Worth It? Erik B. Finger, Terry B. Strom and Arthur J. Matas

Lessons and Limits of Mouse Models Anita S. Chong, Maria-Luisa Alegre, Michelle L. Miller, et al.

Effector Mechanisms of Rejection Aurélie Moreau, Emilie Varey, Ignacio Anegon, et al.

The Innate Immune System and Transplantation Conrad A. Farrar, Jerzy W. Kupiec-Weglinski and Steven H. Sacks

For additional articles in this collection, see http://perspectivesinmedicine.cshlp.org/cgi/collection/ 